\title{
Haloanaerobium fermentans sp. nov., a strictly anaerobic, fermentative halophile isolated from fermented puffer fish ovaries
}

\author{
Takeshi Kobayashi, Bon Kimura and Tateo Fujii
}

Department of Food Science and Technology, Tokyo University of Fisheries, 4-5-7 Konan, Minato-ku, Tokyo1088477, Japan
Author for correspondence: Takeshi Kobayashi. Tel: +8135463 0606. Fax: +81354630602. e-mail: takeshik@tokyo-u-fish.ac.jp

A strain of strictly anaerobic and moderately halophilic bacteria isolated from salted puffer fish ovaries was studied phenotypically, genotypically and phylogenetically. On the basis of its physiological and morphological characteristics, the new isolate is considered to be a member of the genus Haloanaerobium. It is a motile, rod-shaped, non-spore-forming, Gram-negative, obligate anaerobe that grows in the presence of $25 \%(\mathrm{w} / \mathrm{v}) \mathrm{NaCl}$. The optimum salt concentration for growth is $10 \%(w / v)$. It grows well at 15 and $45{ }^{\circ} \mathrm{C}$, but not at 10 or $50{ }^{\circ} \mathrm{C}$. The optimum temperature for growth is $35^{\circ} \mathrm{C}$. It grows at pH 6.0-9.0 and the optimum pH for growth is 7.5. It ferments $\mathbf{N}$ -

acetylglucosamine, cellobiose, fructose, galactose, D-glucose, lactose, maltose, D-mannose, raffinose, D-ribose, sucrose and D-xylose. It ferments D-glucose with the production of hydrogen, carbon dioxide, ethanol and organic acids such as acetate, formate and lactate. 16S rRNA gene sequence information confirmed the phylogenetic position of the new isolate, strain R-9', as a member of the genus Haloanaerobium. DNA-DNA hybridization data revealed that isolate $\mathrm{R}^{-9^{\top}}$ exhibited low levels of reassociation (less than $30 \%$ ) with previously described Haloanaerobium species. Based on these results, the new isolate appears to represent a new Haloanaerobium species, for which the name Haloanaerobium fermentans sp. nov. is proposed. The type strain is R-9 ( = JCM 10494').

Keywords: fermented seafood, halophilic fermentative bacteria, Haloanaerobium fermentans

\section{INTRODUCTION}

Members of the genus Haloanaerobium are widely distributed in surface saline ecosystems such as hypersaline lakes and subsurface ecosystems such as oilfields. Eight species of this genus have been described previously. They have been isolated from various hypersaline environments : the Great Salt Lake (Zeikus et al., 1983; Tsai et al., 1995), Sivash Lake (Zhilina et al., 1992), Retba Lake (Cayol et al., 1994, 1995), gasbearing sandstones and brine waters (Rengpipat et al., 1988), petroleum reservoir fluid (Bhupathiraju et al., 1994, 1999) and oil-injection water (Ravot et al., 1997).

In a previous study, we described halophilic bacteria that grew only anaerobically in the manufacturing

The DDBJ accession number for the $16 \mathrm{~S}$ rRNA gene sequence of strain R-9 $\left(=\mathrm{JCM} 10494^{\top}\right)$ is AB023308. process of a Japanese seafood, puffer fish ovaries fermented with rice-bran or fugunoko nukaduke (Kobayashi et al., 1995), but the detailed characteristics of these anaerobes were not reported. In this study, we undertook a phenotypic, genotypic and phylogenetic characterization of $\mathrm{R}-9^{\mathrm{T}}$, an isolate of the new halophilic anaerobe that is representative of one of the dominant species in these fermented ovaries. The precise identification and phylogenetic position of the new isolate was determined by phenotypic characterization, 16S rRNA gene sequencing and DNADNA hybridization. On the basis of our results, we conclude that our isolate should be placed in a new species of Haloanaerobium.

\section{METHODS}

Bacterial strains and media. A new isolate (R-9 $)$ was obtained previously from salted puffer fish ovaries in the manufacturing process of a Japanese traditional food 
product, fugunoko nukaduke (Kobayashi et al., 1995). To prepare fugunoko nukaduke, puffer fish ovaries are salted for at least 6 months and the ovaries are then fermented naturally with rice-bran, fish sauce and koji for several years. To isolate and purify the new isolate, we used GYP agar containing ( $1^{-1}$ distilled water): $10 \mathrm{~g}$ glucose, $10 \mathrm{~g}$ yeast extract, $5 \mathrm{~g}$ Bactopeptone, $2 \mathrm{~g}$ meat extract (Kyokuto), $2 \mathrm{~g}$ $\mathrm{CH}_{3} \mathrm{COONa} .3 \mathrm{H}_{2} \mathrm{O}, 5 \mathrm{~g} \mathrm{CaCO}, 5 \mathrm{ml}$ salt solution $\left(1^{-1}: 40 \mathrm{~g}\right.$ $\mathrm{MgSO}_{4} \cdot 7 \mathrm{H}_{2} \mathrm{O}, 2 \mathrm{~g} \mathrm{MnSO}_{4} \cdot 4 \mathrm{H}_{2} \mathrm{O}, 2 \mathrm{~g} \mathrm{FeSO}_{4} \cdot 7 \mathrm{H}_{2} \mathrm{O}, 2 \mathrm{~g}$ $\mathrm{NaCl}), 0.25 \mathrm{~g}$ Tween $80,200 \mathrm{~g} \mathrm{NaCl}$ and $12 \mathrm{~g}$ agar. A GasPak anaerobic system (BBL) was used for cultivation. The type strains of Haloanaerobium praevalens (DSM $2228^{\mathrm{T}}$ ), Haloanaerobium acetoethylicum (DSM 3532 ${ }^{\mathrm{T}}$ ), Haloanaerobium saccharolyticum subsp. saccharolyticum (DSM $\left.6643^{\mathrm{T}}\right)$, Haloanaerobium saccharolyticum subsp. senegalense (DSM 7379 $)$, Haloanaerobium alcaliphilum (DSM 8275 $)$, Haloanaerobium lacusrosei (DSM 10165 ) and Haloanaerobium congolense (DSM $\left.11287^{\mathrm{T}}\right)$ were obtained from the DSMZ (Braunschweig, Germany). Haloanaerobium salsuginis ATCC $51327^{\mathrm{T}}$ was obtained from the ATCC (Manassas, VA, USA). Isolate R-9 ${ }^{\mathrm{T}}$ was stabbed into anaerobic bacterial culture medium (ABCM; Eiken) consisting of $\left(1^{-1}\right.$ distilled water $): 3 \mathrm{~g}$ glucose, $5 \mathrm{~g}$ yeast extract, $10 \mathrm{~g}$ peptone, $3 \mathrm{~g}$ soypeptone, $10 \mathrm{~g}$ tryptone, $2 \mathrm{~g}$ plant extract, $5 \mathrm{~g}$ soluble starch, $3 \mathrm{~g}$ meat extract, $2 \mathrm{~g} \mathrm{NaCl}, 2.5 \mathrm{~g}$ $\mathrm{K}_{2} \mathrm{HPO}_{4}, 0.005 \mathrm{~g}$ haemin, $0.3 \mathrm{~g} \mathrm{~L}$-cysteine. $\mathrm{HCl}$ and $0.3 \mathrm{~g}$ sodium thioglycolate, supplemented with $10 \%$ (w/v) $\mathrm{NaCl}$ and $0.5 \% \mathrm{CaCO}_{3}$. The culture was maintained at $5{ }^{\circ} \mathrm{C}$ and subcultured every 6 months. The inocula used were prepared from 48- to 72-h-old cultures in ABCM medium supplemented with $10 \%(\mathrm{w} / \mathrm{v}) \mathrm{NaCl}$ incubated at $30{ }^{\circ} \mathrm{C}$ under anaerobic conditions.

Cultural, physiological and biochemical characteristics. Gram staining was performed as described previously (Dussault, 1955). Cell morphology and motility were observed by light microscope. Cells for electron microscopy were stained with $2 \%(\mathrm{w} / \mathrm{v})$ phosphotungstic acid. Micrographs were taken with a model Hitachi H-7000 electron microscope with an acceleration voltage of $75 \mathrm{kV}$. To test for the formation of endospores, growth was observed after pasteurization at $70{ }^{\circ} \mathrm{C}$ for $10 \mathrm{~min}$. Catalase activity was tested with $3 \%(\mathrm{w} / \mathrm{v})$ $\mathrm{H}_{2} \mathrm{O}_{2}$. Hydrogen sulfide production was determined with sulfide indole motility (SIM) medium (Eiken). Nitrate reduction was tested by using Gifu anaerobic medium (GAM; Nissui) supplemented with $0 \cdot 1 \% \mathrm{KNO}_{3}$ and $0 \cdot 15 \%$ agar. To test for the ability to ferment various carbohydrates, a basic medium (Oren et al., 1984) containing $40 \mathrm{mM}$ PIPES buffer ( $\mathrm{pH} \mathrm{6.6)} \mathrm{was} \mathrm{used.} \mathrm{Changes} \mathrm{in} \mathrm{the} \mathrm{pH}$ of the cultures were measured after $14 \mathrm{~d}$ incubation. The criterion used for positive substrate fermentation was a $\mathrm{pH}$ decrease of at least $0 \cdot 2$. Salt-tolerance tests were carried out with $\mathrm{ABCM}$ medium containing $\mathrm{NaCl}$ at concentrations ranging from 0 to $25 \%(\mathrm{w} / \mathrm{v})$. The range of growth temperatures was also determined in ABCM medium. The effect of $\mathrm{pH}$ on growth was tested in ABCM medium containing $100 \mathrm{mM}$ MOPS buffer. The $\mathrm{pH}$ was adjusted with $4 \mathrm{M} \mathrm{NaOH}$ or $\mathrm{HCl}$. Growth was monitored by measuring the increase in $\mathrm{OD}_{660}$

For the analysis of fermentation products from the medium, the strain was incubated in $15 \mathrm{ml}$ complex medium containing $0.5 \%$ glucose in $30 \mathrm{ml}$ serum bottles under nitrogen gas. For analysis of broth samples, a Shimadzu organic acid analysis system using ion-exclusion chromatography was employed. Ethanol in broth samples was analysed with enzymic kits from Boehringer Mannheim. The gas phase was analysed by a Hitachi G-5000A gas chromatograph equipped with a thermal-conductivity detector. The effect of external electron acceptors on growth was tested in basal medium containing glucose $(10 \mathrm{mM})$ as an electron donor. Compounds tested as electron acceptors included elemental sulfur, sodium sulfite, sodium sulfate, thiosulfate and sodium formate at a concentration of $3 \mathrm{~g} \mathrm{l}^{-1}$.

G + C content of genomic DNA and DNA-DNA hybridization. Genomic DNA was prepared by the procedure of Marmur (1961). DNA-DNA hybridization studies were carried out by the microplate hybridization method with photobiotin labelling and fluorometric detection as described previously (Ezaki et al., 1989). The DNA base composition was determined by the HPLC method as reported previously (Katayama-Fujimura et al., 1984).

16S rRNA gene sequencing and phylogenetic analysis. The 16S rRNA gene was amplified by PCR. Sequencing of the 16S rRNA gene was carried out by using an Applied Biosystems PCR kit (Dye Terminator cycle sequencing kit). For amplification of the $16 \mathrm{~S}$ rRNA gene, a universal primer set was used that corresponded to positions 8-27 (forward primer) and 1492-1510 (reverse primer) of the Escherichia coli numbering system (Weisburg et al., 1991). The reaction mixture was analysed with the Applied Biosystems 373A DNA sequencer as described previously (Satomi et al., 1997). The final sequence was determined from overlapping sequence data using the GENETYX computer program.

Nucleotide substitution rates ( $K_{\text {nuc }}$ values) (Kimura, 1980) were determined and a distance matrix tree was constructed by the neighbour-joining method (Saitou \& Nei, 1987) using the CLUSTAL w program (Thompson et al., 1994). The sequence for positions 99-1359 in the E. coli numbering was used in the analyses.

Reference sequences of other members of the genus Haloanaerobium and related genera were obtained from the DDBJ database. The following sequences were used for analysis (with accession numbers): Haloanaerobium praevalens DSM 2228 $8^{\mathrm{T}}$ (AB022034), Haloanaerobium acetoethylicum DSM 3532 ${ }^{\mathrm{T}}$ (X89071), Haloanaerobium saccharolyticum subsp. saccharolyticum DSM 6643 ${ }^{\mathrm{T}}$ (X89069), Haloanaerobium saccharolyticum subsp. senegalense DSM $7379^{\mathrm{T}}$ (X89070), Haloanaerobium alcaliphilum DSM $8275^{\mathrm{T}}$ (X81850), Haloanaerobium lacusrosei DSM $10165^{\mathrm{T}}$ (L39787), Haloanaerobium congolense DSM $11287^{\mathrm{T}}$ (U76632), Haloanaerobium salsuginis ATCC $51327^{\mathrm{T}}$ (L22890), Haloanaerobium kushneri ATCC 700103 ${ }^{\mathrm{T}}$ (U86446), Halobacteroides halobius DSM 5150" (L37423),

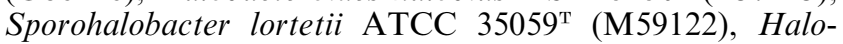
thermothrix orenii OMC 544 ${ }^{\mathrm{T}}$ (L22016) and Megasphaera elsdenii ATCC 17752 (M26493).

\section{RESULTS}

\section{Morphology and cultural characteristics}

Cells of isolate R-9 ${ }^{\mathrm{T}}$ were Gram-negative rods $(1 \cdot 0$ $1 \cdot 2 \mu \mathrm{m}$ wide by $2 \cdot 7-3 \cdot 3 \mu \mathrm{m}$ long). Cells grew only anaerobically on plate medium. Colonies on ABCM plate medium supplemented with $10 \%(\mathrm{w} / \mathrm{v}) \mathrm{NaCl}$ were smooth, convex, opaque and yellowish. Spores were not observed microscopically and no growth was obtained after pasteurization. Strain R-9 ${ }^{\mathrm{T}}$ was motile by means of peritrichous flagella (Fig. 1). 


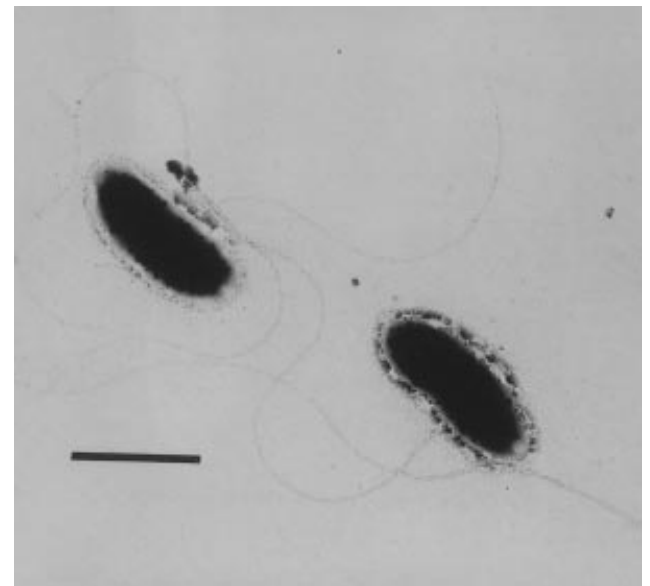

Fig. 1. Transmission electron micrograph of negatively stained cells of Haloanaerobium fermentans strain R-9 ${ }^{\top}$. Bar, $2 \mu \mathrm{m}$.

\section{Physiological and biochemical characteristics}

Isolate R- $9^{\mathrm{T}}$ was not able to grow in the presence of less than $5 \%(\mathrm{w} / \mathrm{v}) \mathrm{NaCl}$ and growth was not inhibited in the presence of $25 \%(\mathrm{w} / \mathrm{v}) \mathrm{NaCl}$. The optimal $\mathrm{NaCl}$ concentration for growth was $10 \%(\mathrm{w} / \mathrm{v})$. Isolate R-9 $9^{\mathrm{T}}$ grew well at 15 and $45^{\circ} \mathrm{C}$ but not at 10 or $50^{\circ} \mathrm{C}$. The optimum temperature for growth was $35^{\circ} \mathrm{C}$. It grew well in the $\mathrm{pH}$ range of 6.0 to $9 \cdot 0$. The optimum $\mathrm{pH}$ for growth was 7.5. It grew in an anaerobic box with a GasPak anaerobic system (BBL) but not outside the anaerobic box. Isolate $\mathrm{R}-\mathrm{9}^{\mathrm{T}}$ fermented $\mathrm{D}$-glucose to hydrogen, carbon dioxide and other acidic endproducts. It produced acetate, formate, lactate and ethanol, but not butyrate or propionate. After $6 \mathrm{~d}$ incubation, isolate $\mathrm{R}-9^{\mathrm{T}}$ had produced $258 \mathrm{mg}$ acetic acid $\mathrm{l}^{-1}, 20 \mathrm{mg}$ formic acid $\mathrm{l}^{-1}, 41 \mathrm{mg}$ lactic acid $\mathrm{l}^{-1}$ and $603 \mathrm{mg}$ ethanol $1^{-1}$ in the broth culture. Isolate R-9 produced hydrogen sulfide on SIM medium. Fer-

Table 1. Differentiation of isolate R $-9^{\top}$ from other Haloanaerobium species on the basis of biochemical and physiological characteristics

H., Haloanaerobium; nT, not tested; \pm , slight growth. Data for other species were taken from Zeikus et al. (1983)

(H. praevalens), Rengpipat et al. (1988) (H. acetoethylicum), Zhilina et al. (1992) (H. saccharolyticum subsp. saccharolyticum), Cayol et al. (1994) (H. saccharolyticum subsp. senegalense), Tsai et al. (1995) (H. alcaliphilum), Cayol et al. (1995) (H. lacusrosei), Ravot et al. (1997) (H. congolense), Bhupathiraju et al. (1994) (H. salsuginis) and Bhupathiraju et al. (1999) (H. kushneri).

\begin{tabular}{|c|c|c|c|c|c|c|c|c|c|c|}
\hline Characteristic & $R-9^{T}$ & 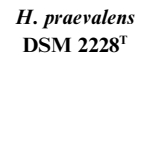 & $\begin{array}{c}H . \\
\text { acetoethylicum } \\
\text { DSM 3532 }\end{array}$ & $\begin{array}{c}H . \\
\text { saccharolyticum } \\
\text { subsp. } \\
\text { saccharolyticum } \\
\text { DSM } 6643^{\mathrm{T}}\end{array}$ & $\begin{array}{c}H . \\
\text { saccharolyticum } \\
\text { subsp. } \\
\text { senegalense } \\
{\text { DSM } 7379^{\mathrm{T}}}^{\mathrm{T}}\end{array}$ & $\begin{array}{c}H . \\
\text { alcaliphilum } \\
\text { DSM 8275 }^{\mathrm{T}}\end{array}$ & $\begin{array}{c}H . \\
\text { lacusrosei } \\
{\text { DSM } \text { 10165 }^{\mathrm{T}}}^{\text {Dof }}\end{array}$ & $\begin{array}{c}H . \\
\text { congolense } \\
{\text { DSM } 11287^{\mathrm{T}}}^{\mathrm{T}}\end{array}$ & $\begin{array}{c}\text { H. } \\
\text { salsuginis } \\
\text { ATCC } 51327^{\mathrm{T}}\end{array}$ & $\begin{array}{c}\text { H. kushneri } \\
\text { ATCC } \\
\text { 700103 }^{\mathrm{T}}\end{array}$ \\
\hline Cell size $(\mu \mathrm{m})$ & $1-1 \cdot 2 \times 2 \cdot 7-3 \cdot 3$ & $0 \cdot 9-1 \cdot 1 \times 2-2 \cdot 6$ & $0 \cdot 4-0 \cdot 7 \times 1-1 \cdot 6$ & $0 \cdot 5-0 \cdot 7 \times 1-1 \cdot 5$ & $0 \cdot 4-0 \cdot 6 \times 2-5$ & $0 \cdot 8 \times 3 \cdot 3-5$ & $0.5 \times 2-3$ & $0 \cdot 5-1 \times 2-4$ & $0 \cdot 3-0 \cdot 4 \times 2 \cdot 6-4$ & $0 \cdot 7 \times 2-3 \cdot 3$ \\
\hline Motility & + & - & + & + & + & + & + & - & - & + \\
\hline $\mathrm{G}+\mathrm{C}$ content $(\mathrm{mol} \%)$ & 33 & 27 & 32 & 31 & 32 & 31 & 32 & 34 & 34 & 34 \\
\hline \multicolumn{11}{|l|}{$\begin{array}{l}\mathrm{NaCl} \text { concentration } \\
(\%) \text { : }\end{array}$} \\
\hline Range & $7-25$ & $2 \cdot 0-30$ & $6-20$ & $3-30$ & $5-25$ & $2 \cdot 5-25$ & $7 \cdot 5-34$ & $4-24$ & $6-24$ & $9-18$ \\
\hline Optimum & 10 & $12 \cdot 5$ & 10 & 10 & $7 \cdot 5-12 \cdot 5$ & 10 & $18-20$ & 10 & 9 & 12 \\
\hline \multicolumn{11}{|l|}{ Temperature $\left({ }^{\circ} \mathrm{C}\right)$ : } \\
\hline Range & $15-45$ & $5-50$ & $15-45$ & $15-47$ & $20-47$ & $25-50$ & $20-50$ & $20-45$ & $22-51$ & $20-45$ \\
\hline Optimum & 35 & 37 & 34 & $37-40$ & 40 & $37-40$ & 40 & 42 & 40 & 40 \\
\hline \multicolumn{11}{|l|}{ pH: } \\
\hline Range & $6 \cdot 0-9 \cdot 0$ & $6 \cdot 0-9 \cdot 0$ & $5 \cdot 4-8 \cdot 0$ & $6 \cdot 0-8 \cdot 0$ & $6 \cdot 3-8 \cdot 7$ & $5 \cdot 8-10$ & NT & $6 \cdot 3-8 \cdot 5$ & $5 \cdot 6-8 \cdot 0$ & $6 \cdot 0-8 \cdot 0$ \\
\hline Optimum & $7 \cdot 5$ & $7 \cdot 0-7 \cdot 4$ & $6 \cdot 3-7 \cdot 4$ & $7 \cdot 5$ & $7 \cdot 0$ & $6 \cdot 7-7 \cdot 0$ & $7 \cdot 0$ & $7 \cdot 0$ & $6 \cdot 1$ & $6 \cdot 5-7 \cdot 5$ \\
\hline \multicolumn{11}{|l|}{ Utilization of: } \\
\hline L-Arabinose & - & NT & NT & + & - & - & - & - & + & + \\
\hline$N$-Acetylglucosamine & + & + & + & + & NT & + & NT & NT & + & NT \\
\hline Cellobiose & + & - & + & + & + & - & + & NT & - & + \\
\hline Fructose & + & + & + & + & + & + & + & + & + & + \\
\hline Galactose & + & - & - & + & - & - & + & + & + & + \\
\hline D-Glucose & + & + & + & + & + & + & + & + & + & + \\
\hline Glycerol & - & - & - & + & + & - & + & NT & - & - \\
\hline Lactose & + & - & + & + & + & - & + & - & + & + \\
\hline Maltose & + & NT & $\mathrm{NT}$ & + & + & + & + & + & + & + \\
\hline D-Mannose & + & + & + & + & + & + & + & + & + & + \\
\hline Pyruvate & - & - & + & + & NT & + & NT & NT & + & + \\
\hline Raffinose & + & NT & NT & - & + & \pm & NT & NT & + & NT \\
\hline D-Ribose & + & NT & NT & + & + & - & + & + & + & NT \\
\hline Rhamnose & - & NT & NT & - & - & - & - & - & + & NT \\
\hline Starch & - & - & - & NT & NT & - & + & NT & - & - \\
\hline Sucrose & + & - & + & + & + & + & + & + & + & + \\
\hline D-Xylose & + & - & + & + & - & - & + & - & + & - \\
\hline Fermentation products & $\begin{array}{c}\text { Acetate, } \\
\text { formate, lactate, } \\
\text { ethanol, } \mathrm{H}_{2}, \\
\mathrm{CO}_{2}\end{array}$ & $\begin{array}{c}\text { Acetate, } \\
\text { butyrate, } \\
\text { propionate, } \mathrm{H}_{2}, \\
\mathrm{CO}_{2}\end{array}$ & $\begin{array}{l}\text { Acetate, ethanol, } \\
\qquad \mathrm{H}_{2}, \mathrm{CO}_{2}\end{array}$ & Acetate, $\mathrm{H}_{2}, \mathrm{CO}_{2}$ & Acetate, $\mathrm{H}_{2}, \mathrm{CO}_{2}$ & $\begin{array}{l}\text { Acetate, } \\
\text { lactate, } \\
\text { butyrate, } \mathrm{H}_{2}, \\
\mathrm{CO}_{2}\end{array}$ & $\begin{array}{l}\text { Acetate, } \\
\text { ethanol, } \mathrm{H}_{2}, \\
\mathrm{CO}_{2}\end{array}$ & $\begin{array}{l}\text { Acetate, } \mathrm{H}_{2}, \\
\quad \mathrm{CO}_{2}\end{array}$ & $\begin{array}{c}\text { Acetate, ethanol, } \\
\mathrm{H}_{2}, \mathrm{CO}_{2}\end{array}$ & $\begin{array}{c}\text { Acetate, } \\
\text { formate, } \\
\text { ethanol, } \mathrm{H}_{2}, \\
\mathrm{CO}_{2}\end{array}$ \\
\hline
\end{tabular}


Table 2. Degree of DNA-DNA relatedness between the new isolate and other Haloanaerobium species

\begin{tabular}{|llc|}
\hline Taxon & \multicolumn{1}{c|}{ Strain } & $\begin{array}{c}\text { Relatedness to } \\
\text { labelled DNA } \\
\text { from R-9 }\end{array}$ \\
\hline New $\mathbf{\%})$
\end{tabular}

H., Haloanaerobium.

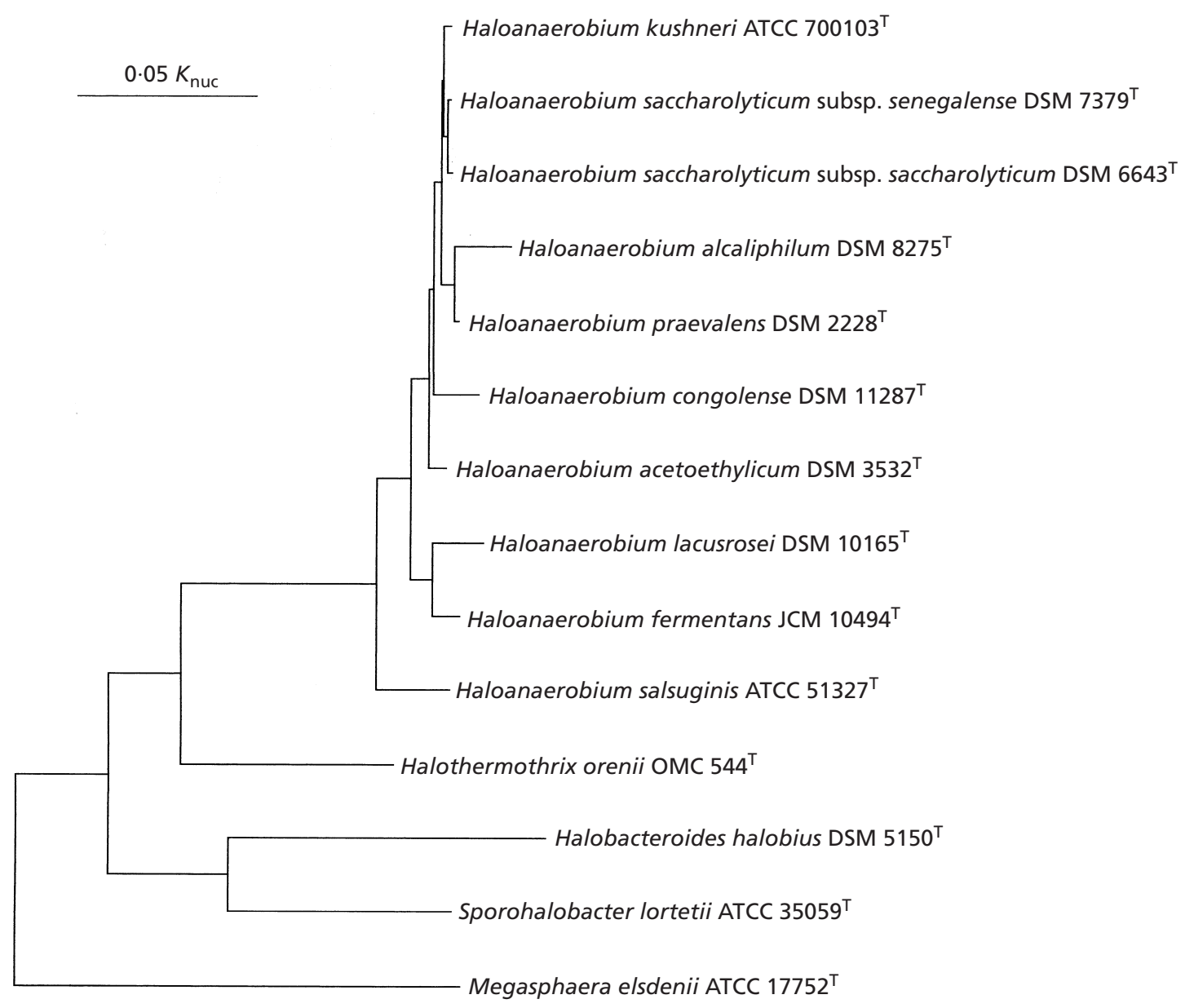

Fig. 2. Phylogenetic tree showing the relationship of Haloanaerobium fermentans strain $R-9^{\top}\left(=J C M 10494^{\top}\right)$ to other strains of the genus Haloanaerobium and related genera based on a comparison of $16 \mathrm{~S}$ rRNA gene sequences. The tree, constructed by the neighbour-joining method (Saitou \& Nei, 1987), was based on a comparison of positions 99-1359 (E. coli numbering; Weisburg et al., 1991). The tree was rooted with Megasphaera elsdenii. 
mentative substrates included $N$-acetylglucosamine, cellobiose, fructose, galactose, D-glucose, lactose, maltose, D-mannose, raffinose, D-ribose, sucrose and D-xylose. L-Arabinose, glycerol, pyruvate, rhamnose and starch were not fermented (Table 1). Sulfate, sulfite, thiosulfate, elemental sulfur and formate did not stimulate the growth of isolate R-9 ${ }^{\mathrm{T}}$.

\section{G + C content of DNA and DNA-DNA hybridization}

The DNA base composition of isolate R- $9^{\mathrm{T}}$ was found to be $33.3 \mathrm{~mol} \% \mathrm{G}+\mathrm{C}$. The levels of DNA hybridization between the new isolate and seven Haloanaerobium species used in this study were less than $30 \%$ (Table 2).

\section{S rRNA gene sequence comparison}

In order to investigate the phylogenetic relationship of isolate $\mathrm{R}-9^{\mathrm{T}}$ to other bacteria, the sequence of a $16 \mathrm{~S}$ rRNA gene PCR product was determined and then analysed. A comparative analysis of the 16S rRNA gene sequences revealed that isolate R- $9^{\mathrm{T}}$ belonged to the low-G + C-content, Gram-positive phylum. Further sequence alignments and phylogenetic analyses show the taxonomic and phylogenetic position of the new isolate to be among the members of the genus Haloanaerobium (Fig. 2). The sequence similarities of isolate R-9T to other Haloanaerobium species ranged from $95.1 \%$ (Haloanaerobium salsuginis) to $97.7 \%$ (Haloanaerobium saccharolyticum subsp. saccharolyticum).

\section{DISCUSSION}

The strain that we investigated is a strictly anaerobic, rod-shaped, fermentative bacterium that is Gramnegative, non-spore-forming and motile by means of peritrichous flagella. It is catalase-negative, moderately halophilic and has a genomic DNA G + C content of $33 \mathrm{~mol} \%$. On the basis of these characteristics, the isolate should be considered a member of the order Haloanaerobiales (Rainey et al., 1995).

The phylogenetic analyses of 16S rRNA gene sequence information clarify the taxonomic and phylogenetic position of isolate $\mathrm{R}-9^{\mathrm{T}}$ in the genus Haloanaerobium. Isolate R-9 $9^{\mathrm{T}}$ could not be accommodated in the same species as any of the seven Haloanaerobium species described previously due to the low DNA-DNA hybridization values (Table 2 ).

Phenotypic studies also revealed that isolate $\mathrm{R}-\mathrm{9}^{\mathrm{T}}$ could not be assigned to any of the previously described species of the genus Haloanaerobium (Table 1). Isolate $\mathrm{R}-9^{\mathrm{T}}$ differs from Haloanaerobium praevalens and Haloanaerobium alcaliphilum in its ability to ferment a wide range of carbohydrates and in its fermentation products (volatile organic acids and ethanol). In addition, isolate R-9 ${ }^{\mathrm{T}}$ and Haloanaerobium praevalens can be differentiated by mo- tility. Haloanaerobium lacusrosei (Cayol et al., 1995) is an extremely halophilic bacterium that grows optimally in $18-20 \%(\mathrm{w} / \mathrm{v}) \mathrm{NaCl}$. Therefore, isolate $\mathrm{R}-9^{\mathrm{T}}$ could be differentiated from Haloanaerobium lacusrosei on the basis of optimal salt concentration, since optimal growth of isolate R-9 $9^{\mathrm{T}}$ was observed in $10 \%$ $(\mathrm{w} / \mathrm{v}) \mathrm{NaCl}$, as well as some differences of substrate profiles, such as the ability to ferment glycerol and starch. Isolate R-9 $9^{\mathrm{T}}$ can be differentiated from Haloanaerobium saccharolyticum (both subspecies) (Zhilina et al., 1992; Cayol et al., 1994) on the basis of its ability to produce ethanol. In addition, the ability to ferment L-arabinose, glycerol, pyruvate and raffinose can be used to differentiate isolate R $-9^{\mathrm{T}}$ from Haloanaerobium saccharolyticum subsp. saccharolyticum. Likewise, the ability to ferment galactose, glycerol and D-xylose can be used to differentiate it from Haloanaerobium saccharolyticum subsp. senegalense. Other combinations of properties distinguish isolate $\mathrm{R}-\mathrm{9}^{\mathrm{T}}$ from the three other Haloanaerobium species: from Haloanaerobium acetoethylicum (Rengpipat et al., 1988) by fermentation of galactose and pyruvate; from Haloanaerobium salsuginis (Bhupathiraju et al., 1994) by fermentation of L-arabinose, cellobiose, pyruvate and rhamnose and by motility; and from Haloanaerobium congolense (Ravot et al., 1997) by fermentation of lactose and D-xylose and by motility.

Recently, Haloanaerobium kushneri was isolated from an oil brine (Bhupathiraju et al., 1999). Since Haloanaerobium kushneri was not included as a reference in the DNA-DNA hybridization study, we could not compare the genotype of our isolate with that of Haloanaerobium kushneri. However, the information available for Haloanaerobium kushneri indicates that there are some differences (ability to ferment Larabinose and some physiological characteristics such as ability to grow at $15^{\circ} \mathrm{C}$ or at $\mathrm{pH}$ values greater than 8.0 ) between this species and our isolate. We compared the 16S rRNA gene sequence of isolate R-9 ${ }^{\mathrm{T}}$ with the sequence of Haloanaerobium kushneri and found a level of similarity of $96.6 \%$. This value is low enough to warrant placement of the two organisms in separate species.

\section{Ecological importance of isolate R-9 $\mathbf{9}^{\top}$ (Haloanaerobium fermentans)}

Because Haloanaerobium fermentans was isolated in the manufacturing process of fermented puffer fish ovaries, its true ecological niche is unknown. However, the presence of this bacterium as one of the dominant species in a salt-preserved food (Kobayashi et al., 1995) indicates the significance of strictly anaerobic, halophilic bacteria during fermentation processes in food products. To our knowledge, there have been few reports of halophilic anaerobes present in food products and associated with the microbiological problems of their manufacturing processes. A halophilic anaerobe, 'Bacteroides halosmophilus', was isolated from Mediterranean salted anchovies (Baum- 
gartner, 1937), but this isolate has been lost. Similar anaerobes were also isolated from a spoiled sample of sugar salted herring (Knøchel \& Huss, 1984a, b), but these isolates were not characterized in detail. Recently, we isolated a strictly anaerobic halophile from canned Swedish fermented herrings (Surströmming) and these isolates were identified as Haloanaerobium praevalens (unpublished data). Therefore, this report is the first description of a novel halophilic anaerobe isolated from food products. In the manufacturing process of salted puffer fish ovaries, as well as in broth medium, significant amounts of organic acids were found; $30-1570 \mu \mathrm{g}$ acetic acid $\mathrm{g}^{-1}, 30-110 \mu \mathrm{g}$ formic acid $\mathrm{g}^{-1}$ and $310-2050 \mu \mathrm{g}$ lactic acid $\mathrm{g}^{-1}$ were detected in the fermented ovaries. These halophilic anaerobes probably contribute to the manufacturing process of this Japanese traditional food product, fermented puffer fish ovaries (fugunoko nukaduke).

\section{Description of Haloanaerobium fermentans sp. nov.}

Haloanaerobium fermentans (fer.men'tans. L. part. adj. fermentans fermenting).

Cells are Gram-negative rods $(1 \cdot 0-1 \cdot 2 \mu \mathrm{m}$ wide by $2 \cdot 7-3 \cdot 3 \mu \mathrm{m}$ long). The bacterium is motile by means of peritrichous flagella. Spores are not observed. Cells grow only anaerobically on solid medium. Colonies on ABCM plate medium supplemented with $10 \%(\mathrm{w} / \mathrm{v})$ $\mathrm{NaCl}$ are smooth, convex, opaque and yellowish. It is a moderately halophilic bacterium that grows in the presence of $7-25 \%(\mathrm{w} / \mathrm{v}) \mathrm{NaCl}$, with an optimal $\mathrm{NaCl}$ concentration of $10 \%(\mathrm{w} / \mathrm{v})$. It grows well at 15 and $45^{\circ} \mathrm{C}$ but not at 10 or $50^{\circ} \mathrm{C}$. The optimum temperature for growth is $35^{\circ} \mathrm{C}$. It grows well in the $\mathrm{pH}$ range of 6.0 to $9 \cdot 0$ with the optimum $\mathrm{pH}$ for growth being $7 \cdot 5$. It ferments D-glucose to hydrogen, carbon dioxide, ethanol and other acidic end-products such as acetate, formate and lactate. Butyrate and propionate are not produced. Hydrogen sulfide is produced. The fermentative substrates include $N$-acetylglucosamine, cellobiose, fructose, galactose, D-glucose, lactose, maltose, D-mannose, raffinose, D-ribose, sucrose and D-xylose. L-Arabinose, glycerol, pyruvate, rhamnose and starch are not fermented. The DNA base composition is $33.3 \mathrm{~mol} \% \mathrm{G}+\mathrm{C}$ (HPLC).

Isolated from salted ovaries in the manufacturing process of a Japanese traditional food product, fermented puffer fish ovaries or fugunoko nukaduke. The 16S rRNA gene sequence of the new isolate R-9 ${ }^{\mathrm{T}}$ has been deposited in the DDBJ database under accession no. AB023308. The type strain is $\mathrm{R}-9^{\mathrm{T}}$, which has been deposited with the Japan Collection of Microorganisms under accession number JCM $10494^{\mathrm{T}}$.

\section{ACKNOWLEDGEMENTS}

The authors thank Y. Touda for supplying salted puffer fish ovaries. We are also grateful to M. Shimoda in our laboratory for her technical assistance. This study was partly supported by a Grant-in-Aid from the Ministry of Education, Science, Sports and Culture of Japan (B 09460094).

\section{REFERENCES}

Baumgartner, J. G. (1937). The salt limits and thermal stability of a new species of anaerobic halophile. Food Res 2, 321-329.

Bhupathiraju, V. K., Oren, A., Sharma, P. K., Tanner, R. S., Woese, C. R. \& Mclnerney, M. J. (1994). Haloanaerobium salsugo sp. nov., a moderately halophilic, anaerobic bacterium from a subterranean brine. Int J Syst Bacteriol 44, 565-572.

Bhupathiraju, V. K., Mclnerney, M. J., Woese, C. R. \& Tanner, R. S. (1999). Haloanaerobium kushneri sp. nov., an obligately halophilic, anaerobic bacterium from an oil brine. Int J Syst Bacteriol 49, 953-960.

Cayol, J.-L., Ollivier, B., Lawson Anani Soh, A. \& 7 other authors (1994). Haloincola saccharolytica subsp. senegalensis subsp. nov., isolated from the sediments of a hypersaline lake, and emended description of Haloincola saccharolytica. Int J Syst Bacteriol 44, 805-811.

Cayol, J.-L., Ollivier, B., Patel, B. K. C., Ageron, E., Grimont, P. A. D., Prensier, G. \& Garcia, J.-L. (1995). Haloanaerobium lacusroseus sp. nov., an extremely halophilic fermentative bacterium from the sediments of a hypersaline lake. Int $J$ Syst Bacteriol 45, 790-797.

Dussault, H. P. (1955). An improved technique for staining red halophilic bacteria. J Bacteriol 70, 484-485.

Ezaki, T., Hashimoto, Y. \& Yabuuchi, E. (1989). Fluorometric deoxyribonucleic acid-deoxyribonucleic acid hybridization in microdilution wells as an alternative to membrane filter hybridization in which radioisotopes are used to determine genetic relatedness among bacterial strains. Int J Syst Bacteriol 39, 224-229.

Katayama-Fujimura, Y., Komatsu, Y., Kuraishi, H. \& Kanako, T. (1984). Estimation of DNA base composition by high performance liquid chromatography of its nuclease P1 hydrolysate. Agric Biol Chem 48, 3169-3172.

Kimura, M. (1980). A simple method for estimating evolutionary rates of base substitutions through comparative studies of nucleotide sequences. J Mol Evol 16, 111-120.

Knøchel, S. \& Huss, H. H. (1984a). Ripening and spoilage of sugar salted herring with and without nitrate. I. Microbiological and related chemical changes. J Food Technol 19, 203-213.

Knøchel, S. \& Huss, H. H. (1984b). Ripening and spoilage of sugar salted herring with and without nitrate. II. Effect of nitrate. J Food Technol 19, 215-224.

Kobayashi, T., Okuzumi, M. \& Fujii, T. (1995). Microflora of fermented puffer fish ovaries in rice-bran 'Fugunoko Nukazuke'. Fish Sci 61, 291-295.

Marmur, J. (1961). A procedure for the isolation of deoxyribonucleic acid from micro-organisms. J Mol Biol 3, 208-218.

Oren, A., Weisburg, W. G., Kessel, M. \& Woese, C. R. (1984). Halobacteroides halobius gen. nov., sp. nov., a moderately halophilic anaerobic bacterium from the bottom sediments of the Dead Sea. Syst Appl Microbiol 5, 58-69.

Rainey, F. A., Zhilina, T. N., Boulygina, E. S., Stackebrandt, E., Tourova, T. P. \& Zavarzin, G. A. (1995). The taxonomic status of the fermentative halophilic anaerobic bacteria: description of Haloanaerobiales ord. nov., Halobacteroidaceae fam. nov., Orenia gen. nov. and further taxonomic rearrangements at the genus and species level. Anaerobe 1, 185-199. 
Ravot, G., Magot, M., Ollivier, B., Patel, B. K. C., Ageron, E., Grimont, P. A. D., Thomas, P. \& Garcia, J.-L. (1997). Haloanaerobium congolense sp. nov., an anaerobic, moderately halophilic, thiosulfate- and sulfur-reducing bacterium from an African oil field. FEMS Microbiol Lett 147, 81-88.

Rengpipat, S., Langworthy, T. A. \& Zeikus, J. G. (1988). Halobacteroides acetoethylicus sp. nov., a new obligately anaerobic halophile isolated from deep subsurface hypersaline environments. Syst Appl Microbiol 11, 28-35.

Saitou, N. \& Nei, M. (1987). The neighbor-joining method: a new method for reconstructing phylogenetic trees. Mol Biol Evol 4, 406-425.

Satomi, M., Kimura, B., Mizoi, M., Sato, T. \& Fujii, T. (1997). Tetragenococcus muriaticus sp. nov., a new moderately halophilic lactic acid bacterium isolated from fermented squid liver sauce. Int J Syst Bacteriol 47, 832-836.

Thompson, J. D., Higgins, D. G. \& Gibson, T. J. (1994). CLUSTAL $\mathrm{W}$ : improving the sensitivity of progressive multiple sequence alignment through sequence weighting, position-specific gap penalties and weight matrix choice. Nucleic Acids Res 22, 4673-4680.

Tsai, C.-R., Garcia, J.-L., Patel, B. K. C., Cayol, J.-L., Baresi, L. \& Mah, R. A. (1995). Haloanaerobium alcaliphilum sp. nov., an anaerobic moderate halophile from the sediments of Great Salt Lake, Utah. Int J Syst Bacteriol 45, 301-307.

Weisburg, W. G., Barns, S. M., Pelletier, D. A. \& Lane, D. J. (1991). $16 \mathrm{~S}$ ribosomal DNA amplification for phylogenetic study. $J$ Bacteriol 173, 697-703.

Zeikus, J. G., Hegge, P. W., Thompson, T. E., Phelps, T. J. \& Langworthy, T. A. (1983). Isolation and description of Haloanaerobium praevalens gen. nov. and sp. nov., an obligately anaerobic halophile common to Great Salt Lake sediments. Curr Microbiol 9, 225-234.

Zhilina, T. N., Zavarzin, G. A., Bulygina, E. S., Kevbrin, V. V., Osipov, G. A. \& Chumakov, K. M. (1992). Ecology, physiology and taxonomy studies on a new taxon of Haloanaerobiaceae, Haloincola saccharolytica gen. nov., sp. nov. Syst Appl Microbiol 15, 275-284. 